\title{
REVIEW ARTICLE \\ Family support and the child as health promoting agent in the Arctic - "the Inuit way"
}

\author{
RA Montgomery-Andersen ${ }^{1}$, I Borup ${ }^{2}$ \\ ${ }^{1}$ Nordic School of Public Health, Nuuk, Greenland \\ ${ }^{2}$ Nordic School of Public Health, Göteborg, Sweden
}

Submitted: 24 October 2011; Revised: 21 December 2011; Published: 3 May 2012

\section{Montgomery-Andersen RA, Borup I}

Family support and the child as health promoting agent in the Arctic - "the Inuit way" Rural and Remote Health 12: 1977. (Online) 2012

Available: http://www.rrh.org.au

A B S T R A C T

Introduction: In the context of the UN's 1990 'Convention on the Right's of the Child' 1990, and the associated definition of health promotion as a community's ability to recognise, define and make decisions on how to create a healthy society, this article describes and analyses how family support networks are conceived and present themselves in perinatal Inuit families.

Methods: This literature review conducted an initial and secondary search using the keywords and combinations of the keywords: healthy families, health promoting families, resiliency, Arctic, Inuit, Family support, was executed in PubMed, Popline, CSA and CINAHL. The tertiary literature search was then combined with literature gleaned from literature lists, and other relevant articles were selected.

Results: Individual members of the family contribute to the health of the family, but the child is often the catalyst for health promotion within the family, not only the siblings to the unborn child, but also the unborn child. Perinatal entities create their own networks that support and develop concepts of family and support systems. Resiliency, kinship and ecocultural process within the family are concomitant to the health of perinatal family and of the children.

Conclusion: More research is needed that moves children from being viewed as the receivers of health towards being seen as the promoters of health and an important actor as health promoting agent within the family.

Key words: child health promotion, ecocultural pathways, Greenland, health promoting agents, health promotion, Inuit, resiliency, social network. 


\section{Introduction}

\section{Human rights and health promotion}

On 10 December 1948 the General Assembly of the United Nations adopted and proclaimed the Universal Declaration of Human Rights, followed by the establishment of The Commission on the Status of Women in 1948, declaring that women's rights were also human rights. It took over 40 years before the 'Convention on the Right's of the Child' (CRC) was ratified to support the child's right to life, to survival and healthy development ${ }^{1}$. Children's rights and human rights are interconnected and the child's right to life, survival and development is directly connected to family, social and public policy, which enable families and children to have control over their own health. This links CRC to WHO's 1984 document on health promotion, with the definition of health promotion as a community's ability to recognise, define and make decisions on how to create a healthy society, a process that empowers and develops local solutions to local challenges.

Although change and the development of new norms have replaced traditional customs within Inuit society, there are still traditions connected with becoming a family that remain an integral part of cultural practices ${ }^{2}$. In Greenland Indigenous cultural beliefs, those concerning children and childhood have been based on the Inuit perception that children develop their own 'consciousness' in early childhood and this moment is awaited by the adults and celebrated in the family (Klaus Georg Hansen; pers comm; 10 July 2005: this is the only known compilation that reviews the Greenlandic Inuit's traditional childrearing philosophies). These postulates are supported in resiliency research within Indigenous peoples and have evolved to be defined as 'cultural resiliency factors' unique to these groups ${ }^{3-5}$. Edward Schor stated that the health of children is directly related to their family life and network ${ }^{6}$. This concept is accepted by many, but what is not always transparent is how this relationship directly influences the health and wellbeing of the child. The purpose of this article was to describe and analyse how Inuit family support networks are conceived and present themselves in these perinatal families. In this article the child's place within the family sphere is explored, as well as the concomitant qualities, within the individual, the family, the community and culture that are the basis for strength and support and resiliency factors as a base for family support network and the child as a health promoting agent. The child is addressed as an integral part of the family, and the unborn child, its siblings and the social construction of the perinatal family are examined. In addition the concept of the child as a health-promoting agent within families is explored.

\section{Methods}

This literature study used Weber's methods of content analysis ${ }^{7}$. Although Weber focused mainly on the use of computers in the classification process, he also systematised and presented the use of content analysis in qualitative studies and discussed the theoretical rationale behind both classification and interpretation ${ }^{7}$. It is often argued that such systematisation does not do justice to the richness of the text; however, Weber's transparent method addresses this issue and divides content analysis into two equally important processes: representation and interpretation.

Representation is the systematic presentation, coding and categorisation of the text by the researcher; interpretation is the use of theory to analyse and present the text. The representation process includes testing reliability, where reproducibility and accuracy are also tested. It examines validity among concepts, variables and methods; validity of classification schemes and finally the creation and testing of coding schemes. Coding includes defining categories, test coding, assessment of reliability, revision of coding rules and/or evaluation of accuracy of coding. Weber argued that both human-based coding procedures and computer coding lack the ability to represent the richness of the spoken language and stated that it is the interpretation process, which 
includes the use of theory throughout the entire analysis process that influences accuracy, validity and reliability.

The present literature search focused on topics of family supports systems, healthy families and the child as the health-promoting actor. Primary and secondary searches were executed using the keywords and combinations of keywords: healthy families, health promoting families, resiliency, Arctic, Inuit, family support. Although one of the goals was to focus on the Nordic countries of the Arctic including Sweden, Finland and Norway, no relevant articles were found in the primary searches of PubMed, Popline, CSA and CINAHL. The tertiary literature search was then combined with literature gleaned from literature lists and 13 other relevant articles were selected (Table 1).

\section{Results}

The literature review helped to clarify and highlight several important subjects pertaining to the focus of the article: resiliency and religiosity; adoption and name-giving; and family support and 'ecocultural' pathways. The lack of relevant articles on the subject of the article was a challenge; however, by focusing on similarities in different cultures, especially Indigenous and disenfranchised groups, it was possible to use the knowledge already extracted about the child as the health-promoting actor in the family and the use of family networks in the Greenlandic arctic to promote health.

\section{Resiliency, religiosity and adoption of kin in the Arctic family}

For decades resiliency research has focused on Indigenous peoples, subcultures and the disenfranchised. Social researchers of the north and anthropologists have looked to culture-specific resiliency factors, relational world-views and resiliency knowledge when describing how 'child health' and 'family' are interconnected. Resiliency theories have been developed both within and outside of cultures and these have been the basis for many communitybased and action- research projects. Ladd-Yelk identified and defined six factors conducive to resilient behaviour ${ }^{3}$ : (i) supportive social networks; (ii) flexible relationships within the family; (iii) religiosity; (iv) extensive use of extended family helping arrangements; (v) the adoption of fictive kin who become family (in the present article this is called adoption of kin/and or kinship); and (vi) strong identification with their racial/ethnic/cultural group. Social networks that are supported by the community are quite common in ethnic groups and communities ${ }^{8}$. According to Cross, the individual is supported by community and is also expected to be a part of the network that supports other members of the community ${ }^{8}$. The concepts of ethnicity, kin and culture blend and become difficult to differentiate. Those not having large family networks are included by adoption: by adopting families, members of the community adopt children or allow themselves to be adopted. This can happen at every time and phase of life and is not necessarily associated with childlessness. This flexibility in family relationships is supported by the use of 'soul names'. Soul names have several purposes and functions, such as supporting and cementing social ties. These kinship relations can be counted as adoptive kin, people who become family. Another support and strengthening mechanism is identification within the racial, ethnic or cultural group ${ }^{3}$. It also describes this concept as a 'relational world view', stating that kinship and relationships to kin influence the equilibrium of peoples' lives $^{8}$. It is often a conscious decision within the family to support and strengthen ties that are important for continuation of kinship relations.

\section{Name giving}

Name giving and soul names create kinship and thus increase the size and strength of kinship or social relations ${ }^{9}$. Through the name-sharing relationship there is an enormous range of other possible relationships. It is a matter of choice how far or how personal a relationship a person wishes to develop a relationship based on kin terms applied to a name-sharer's father or other family member. The resiliency factors of religiosity and adoptive kin have a great influence on the health of Indigenous families ${ }^{3,10}$. Religiosity as a concept is seldom found in the health literature relating to Greenland; however, spiritual connectedness, soul names and kinship with the child as the central figure are seen as important to the Inuit and Indigenous peoples of the north ${ }^{18}$. 


\begin{tabular}{|c|c|c|c|}
\hline Ref & Title & Content & Comments \\
\hline 2 & $\begin{array}{l}\text { Cultural well-being and cultural } \\
\text { vitality }\end{array}$ & $\begin{array}{l}\text { Social network and kinship in the Arctic } \\
\text { Description of how these traditions have developed } \\
\text { and changed over the past } 50 \text { years } \\
\text { Looks at how the Inuit communities have embraced } \\
\text { new knowledge and seek to use it to develop and } \\
\text { secure their communities }\end{array}$ & $\begin{array}{l}\text { Looks at the Inuit peoples of the North as } \\
\text { one people with one culture. Does not } \\
\text { take into account the different colonial } \\
\text { powers influence and the geophysical } \\
\text { differences of the Inuit peoples }\end{array}$ \\
\hline 4 & $\begin{array}{l}\text { Resiliency factors of the North- } \\
\text { American Indigenous people }\end{array}$ & $\begin{array}{l}\text { Descriptive research concerning resiliency factors in } \\
\text { Indigenous peoples. Gives an overview of resiliency } \\
\text { factors in Native American families. Reviews factors } \\
\text { that can be defined as culturally specific resiliency } \\
\text { factors }\end{array}$ & $\begin{array}{l}\text { Theoretically a very interesting and } \\
\text { important article. Lacks the Inuit focus } \\
\text { but has a very good description of } \\
\text { resiliency factors among indigenous } \\
\text { peoples }\end{array}$ \\
\hline 7 & Family Pathways to Child Health & Looks at eco-cultural pathways in families & $\begin{array}{l}\text { Has no reference to indigenous or } \\
\text { minorities }\end{array}$ \\
\hline 9 & $\begin{array}{l}\text { Understanding family resiliency from } \\
\text { a relational world-view }\end{array}$ & $\begin{array}{l}\text { Resiliency with special focus on culturally specific } \\
\text { resiliency is explored. }\end{array}$ & - \\
\hline 10 & $\begin{array}{l}\text { Kinship in Greenland - emotions of } \\
\text { relatedness }\end{array}$ & $\begin{array}{l}\text { Presents the basic ideology around kinship in the } \\
\text { Greenlandic Arctic is presented both within the urban } \\
\text { and the traditional Inuit/ Greenlandic context. } \\
\text { Examines: expectation, moral and mutual obligations } \\
\text { such as 1) sharing, 2) naming, 3) adoption and 4) } \\
\text { friendship }\end{array}$ & $\begin{array}{l}\text { Specifically about the Inuit people and } \\
\text { focuses on resiliency and cultural } \\
\text { traditions concerning kinship that is } \\
\text { specific to the people of Greenland. Has } \\
\text { no focus on the child as a catalyst or a } \\
\text { independent actor }\end{array}$ \\
\hline 11 & $\begin{array}{l}\text { Arctic Homeland: Kinship, } \\
\text { Community and Development in } \\
\text { Northwest Greenland }\end{array}$ & $\begin{array}{l}\text { How kinship, community a network are understood } \\
\text { in an Arctic setting } \\
\text { Describes the concept of name giving and how this } \\
\text { can effect concepts of kin and family }\end{array}$ & $\begin{array}{l}\text { Is specifically about Inuit people and } \\
\text { focuses on resiliency and cultural } \\
\text { traditions of name giving that is specific } \\
\text { to the people of Greenland }\end{array}$ \\
\hline 12 & $\begin{array}{l}\text { The canary, the whale and the Inuit. } \\
\text { In: Childbirth and Authorative } \\
\text { Knowledge- Cross-cultural } \\
\text { perspectives }\end{array}$ & $\begin{array}{l}\text { How knowledge is perceived in the Inuit arctic in } \\
\text { relation to childbirth and the family } \\
\text { Presents the concept of logics as a means of } \\
\text { understanding the different actors in the birthing } \\
\text { process }\end{array}$ & $\begin{array}{l}\text { Direct research pertaining to the Inuit } \\
\text { people of the North. Has an adult } \\
\text { perspective, but involves the family, the } \\
\text { community and the policymakers as well } \\
\text { as the perinatal family }\end{array}$ \\
\hline 13 & $\begin{array}{l}\text { Births and power: social change and } \\
\text { the politics of reproduction }\end{array}$ & $\begin{array}{l}\text { Describes birth and birth practices and how power } \\
\text { and policies influence the health of perinatal families }\end{array}$ & $\begin{array}{l}\text { Research pertaining to the Inuit people of } \\
\text { the North. Does not include research on } \\
\text { the Greenlandic people }\end{array}$ \\
\hline 14 & $\begin{array}{l}\text { The health-promoting family: a } \\
\text { conceptual framework for future } \\
\text { research }\end{array}$ & $\begin{array}{l}\text { Family support networks, salutogenesis, health } \\
\text { promotion, healthy families } \\
\text { The child as a health promoting actor within the } \\
\text { family; model of the health promoting family; eco- } \\
\text { cultural pathways }\end{array}$ & $\begin{array}{l}\text { Focus on the concept of the child as a } \\
\text { health promoting agent. Does not focus } \\
\text { on Inuit, people of the north nor } \\
\text { Indigenous peoples }\end{array}$ \\
\hline 15 & $\begin{array}{l}\text { Adolescence and changing family } \\
\text { relations in the Central Canadian } \\
\text { Arctic }\end{array}$ & $\begin{array}{l}\text { Family support networks, the Arctic, healthy families } \\
\text { Changes in the Inuit life and family structure; } \\
\text { challenges for families }\end{array}$ & $\begin{array}{l}\text { Focus on the family as a support. Direct } \\
\text { research concerning the Inuit people of } \\
\text { Canada, does not take other Inuit peoples } \\
\text { into account }\end{array}$ \\
\hline 16 & $\begin{array}{l}\text { The role of social relations in health } \\
\text { promotion }\end{array}$ & $\begin{array}{l}\text { Family support networks, health promotion } \\
\text { Development of psychosocial interventions; } \\
\text { promotion of social supports }\end{array}$ & $\begin{array}{l}\text { Good theoretical article on family } \\
\text { support and its importance to the child } \\
\text { and family. No focus on the Inuit }\end{array}$ \\
\hline 17 & $\begin{array}{l}\text { There should be more help out here! } \\
\text { A qualitative study of the needs of } \\
\text { Aboriginal adolescents in rural } \\
\text { Australia }\end{array}$ & $\begin{array}{l}\text { Family support networks, rural areas, salutogenesis, } \\
\text { healthy families } \\
\text { Social norms; support and use of family support, } \\
\text { family mentoring }\end{array}$ & $\begin{array}{l}\text { Article presents young Indigenous } \\
\text { peoples own experience of family support } \\
\text { and its importance. Does not have a } \\
\text { counterpart that looks at Inuit youth }\end{array}$ \\
\hline 18 & $\begin{array}{l}\text { Social support, material circumstance } \\
\text { and health behaviour: Influences in } \\
\text { First Nation and Inuit communities of } \\
\text { Canada }\end{array}$ & $\begin{array}{l}\text { Social support systems within the Arctic and first } \\
\text { nations of Canada. Overview of First Nations and } \\
\text { Inuit communities in Canada and the development of } \\
\text { health care systems that serve these communities }\end{array}$ & $\begin{array}{l}\text { Not specifically focused on the Inuit. } \\
\text { Good comparative document }\end{array}$ \\
\hline
\end{tabular}

Ref, Reference list number. 


\section{Kinship and the perinatal family in Greenland}

Trondheim took the stand that rapid urbanization and modern civilisation has not destroyed the culture of Greenland ${ }^{9}$. She believes that traditional relationships such as kinship have simply taken on a new form, created within the society around the traditional concepts. Traditional family systems, networks and kinship relationships have changed outwardly, but it is not known whether these changes are detrimental or conducive to the families and to the children who are the centre of the family ${ }^{2,9}$. By acknowledging the perinatal family (in the present article the perinatal period is defined as the period from acknowledgement of pregnancy until the new born is one month old) as an entity, both the unborn child and individual members of the family unit are respected as individuals. The concept of the perinatal family acknowledges change and developments in family dynamics during pregnancy, and effects on each individual member of the family. The birth of a new family member influences not only the wellbeing of the whole family, but also the life of the other children in the family. The family is defined by the invisible lines that are created by kinship practices and family constellation within the individual 'perinatal family'. Kinship can exist or can be created through genealogy, consanguinity, affinity, adoption, naming, friendship or colleagues ${ }^{9}$. The focus of the present study is on the health-promoting influence of the child on family and kinship relations; not only acknowledging that they exist, but also establishing why these relations are important.

\section{The perinatal family}

The perinatal period spans from conception until one month of age, during which time the unborn child, the mother and partially the father are the focal points. The family nucleus is seen as an isolated entity; however, the conception and birth of a child changes the way that society perceives the concept of family ${ }^{11,19}$. Perinatal care, childbirth and post-natal support are different in different cultures and countries and the concept of family is influenced by cultural customs. O'Neil and Kaufert presented the hypothesis of power in the perinatal room ${ }^{12}$. This theory is based on the concept that place of birth, mobility and decision-making around childbirth are and will be a power struggle between the family unit and the political unit. By agreeing or not agreeing to the national, regional or local policies around childbirth, the power of the governments is either rejected or accepted by the individual family. Daviss reinforced this theory in her article 'The Canary, the Whale and the Inuit ${ }^{11}$. She described the tension and contradictions that exist between traditional and medical; between culture and policy. Daviss identified several areas where the definition of the perinatal family and its autonomy can be challenged by policy ${ }^{11}$ :

The kinship system rests on the social cornerstone of
cooperation, wherein participation in a social forum, is an
important principle. The participants in the system have to be
an active participate in order to support the close social links.
Active participation within the family is especially important
in order to support and sustain the close relation to the
created family.

\section{The child as the health-promoting agent}

Children are the focus of many programs and theories of empowerment and health promotion. They are seen as the future of our civilization; however, children have limited control over their lives in our societies. Cassidy stated that although the children in a community are often the objects of health promotion projects and programs, they are seldom involved in the definition, development or evaluation ${ }^{20}$. She presented the viewpoint that children have a very limited control over their own lives and suggested that it is in the limitation and formation of these limitations that we develop many of our empowerment efforts and democratization processes. She underlined the lack of choice that children have and the power that adults have over children. She stated that we 'educate' to fulfil the wishes of adults and that we measure the health of our societies by how well children fulfil the expectations of the adult population ${ }^{20}$. 
Christensen focused on the language and thoughts of the children themselves, bringing the focus towards what each individual member of the family contributes to the whole ${ }^{13}$. She sees the child as the catalyst to healthy habits and experienced health within the family. By viewing the child as an equally important part of the family, the child has a direct and important influence on the health of the society at large. Cassidy $^{20}$ supported Christensen's theories and quoted McCall's ${ }^{21}$ philosophical inquiry theories. She stated that ideas and concepts such as beauty and truth, for example, are just as easy for children to understand as adults. When presented with the same philosophical topics, children voice the same questions as their adult counterparts, although they do not have the same life experience.

\section{What is the health-promoting family?}

The family unit and its responsibilities have changed dramatically in all parts of the world. In the Arctic among the Inuit the change has been drastic and quick. While these changes in northern and southern Europe have occurred over a hundred-year period, the same changes among the Inuit have occurred mainly in the 1900s, and especially in the period following World War $\mathrm{II}^{14}$. This has influenced parenting and the establishment of family and kinship relationships, and thus has influenced family support in families in Arctic Inuit communities. When examining support networks, it is important to focus on why these networks are important, not only that they exist.

Improvement in or maintenance of the health of the individual is influenced not only by the individual's behaviour, but also by the behaviours of others in their network ${ }^{15}$. When defining healthy families, the concept of the health-promoting family has emerged and the family as an entity has been described, defined and assessed in research. Christensen uses a model that distinguishes external and internal factors associated with health-promoting families. Family support networks as described by Christensen are considered tools to support families with new-born or young children. One ground-breaking hypothesis is the child as the health-promoting actor, entailing a shift from viewing the child as the object of health initiatives to the child being the subject of health initiatives and a social being in his or her own right ${ }^{22}$.

\section{Family support}

More than 30 years ago, sociologist developed the idea that social conditions might influence health status. Epidemiologists looked at the extent to which social support networks and especially the family could influence the health and wellbeing of communities ${ }^{15}$. This has not been examined in Greenland nor have the children's or youth's voices been represented in research. Not so in rural areas of Australia. When young people were asked to whom they turned for general advice, all participants agreed that they preferred to discuss their problems with family members, mainly parents, siblings, aunts and uncles ${ }^{16}$. These Aboriginal researchers focused on the family and the health-promoting families within the context of families with youth and young adults ${ }^{16}$. To the question: 'Who should help young people?', a male Aboriginal youth stated: '...my family has most effect on $\mathrm{me}^{\prime 16}$. It was not only the amount of support given but the interval of contact with support persons that was important.

\section{Ecocultural pathways}

According to Richmond and Ross, external factors such as society and community influence the lives and health of families. The same can be said about internal factors. There is much discussion about whether the interconnectedness that exists the Indigenous communities is of a health-promoting or detrimental dimension ${ }^{17}$. The term 'ecocultural' covers a method of conceptualizing the ways in which families engage with and utilize the resources at their disposal, with the family's health practices as the main element. Ecocultural pathways focus on which habits and cultural traditions within the family have a healthy influence on the family as a whole, but especially on the children within a family. Christensen theorises that children are often the health-promoting actors within the family ${ }^{13}$. Several authors support the theory, agreeing that health within the family unit is influenced not only by the individual family members' behaviour, but also 
the ability of the child and the individual members to communicate with each other ${ }^{15}$.

\section{Discussion}

\section{Words, the perinatal family and concepts of kinship}

To have words at your command is power, but there is also power in unspoken concepts. Individual words such as family, kinship, network and relationship can be the keys to understanding culture, philosophy or the concept of the child and their family ${ }^{18}$. In other words, the same words can have several meanings depending on the cultural context, each word having a definition and a concomitant connotation that is ethnically and culturally accessible. As Needham poetically put it: '... the most difficult task in social anthropological fieldwork is to determine the meaning of a few key words ${ }^{\prime 18}$.

The perinatal family often consist of grandparents, cousins, aunts and other siblings, and yet these members do not often to make their way into the literature and seem to have an invisible, undefined space. Concepts of family network and kinship relationships are changing in the Arctic; however, the people of Greenland, Arctic Canada and Alaska hold on to many of the traditions of religiosity, reciprocity and kinship. Family networks change and develop to support and fit in with the needs of the time, and the political and economical systems that the family lives within ${ }^{2,9}$. Perinatal families create their own networks through the use of resiliency factors such as those of religiosity and adoptive kin. With the giving of soul names, both religiosity and kinship are constructed with the child as central figure. Support is created with the giving of names: family ties are reconstructed and networks are solidified. Many Greenlanders are reluctant to put defining words to why they continue to adopt kin and use the tradition of soul names. But they are conscious of this important part of their culture and often either choose to or not to continue these traditions. Through the use of soul names, religiosity and kinship are bound together in one single act. The establishment and development of kinship bonds among family are a vital means of creating and supporting the individuals within those families. This has been and still is an important part of the Greenlandic culture and other cultures of the north. This tradition is clearly defined here but is also present in other cultures of the world.

\section{Ecocultural pathways and the child as the health- promoting agent}

The ability to thrive in adverse or difficult conditions is one of the keys to survival has also been a subject of study when trying to decipher what supports healthy children. Resiliency seems to correlate with cultural practices and is concomitant to the 'relational world view'. The family's conscious decision to support and strengthen kinship relations has an influence on the health of the children and their families. The healthpromoting family is a concept that strives toward developing tools and methods that support and encourage healthy ways of interacting and communicating in families. This seems to be important not only for children, youth and young adults, but also for adults and elders who have described the importance of meaningful interaction.

Family constellation changes from family to family and from culture to culture but the concept of children being the healthpromoting actors is a newer concept. According to Christensen, contemporary families have their own goals and values and through daily practices and activities attempt to achieve these goals $^{13}$. Enablement, meaningfulness and participation are all concepts that are interconnected with health-promoting families and family support. Often perceived support or the belief that support was available is an important marker when assessing the success of interventions ${ }^{23}$. Not only when looking at the adult perspective of family, but also for youth and children. Christensen referred to WHO's research from 2001, where five important factors for young people's health are described: (i) meaningful relationships with adults and peers; (ii) parental structure and boundaries for behaviour; (iii) encouragement of self-expression; (iv) educational, economic and social opportunities; and (v) minimal risk of injury, exploitation or disease ${ }^{13}$. Christensen argued that by taking an ecocultural approach to family and family support networks, one goes beyond looking at 'what types of 
families do what' (one parent, two parent, native, non-native). The focus becomes what individual families do to promote their health, family goals, values and practices ${ }^{13}$. This makes it possible to focus on the influence of child on the health of the family. The different authors present different theories but there is agreement that the family is a great influence not only on the life of the child, but also on the wellbeing of the whole family.

The perinatal family is not mentioned in any of the literature and this may be because it is not deemed an important enough entity, or because the mother and unborn/new-born child is often looked upon as an isolated entity, not influenced by the outside world. By acknowledging the perinatal family as an entity, both the unborn child and each member of the family unit are respected as an individual. The siblings that already are a part of the family unit, their health and how they are perceived by the parents and the extended family influence the health of the entire family.

\section{Further research}

Niclasen described and suggested comprehensive indicators for analysing and assessing health of the children ${ }^{24}$. She also suggested the development of a system of child health indicators that can map the health of children in the Arctic to enable comparison with other countries and among regions of the Arctic. Kostenius presented the Save the Children Alliance's toolkit of good practice ${ }^{25}$. Both offer windows to how public health and health promotion scientists can continue to develop an understanding of the child as the health-promoting agent. A move is needed from quantifying the health of the child to qualifying the strengths and challenges that influence the health of the child in perinatal families, focusing on the child as the health-promoting agent in Artic and northern families.

\section{Limitations}

Weber's method of content analysis as a framework for categorising and analysing data was used both in the representation and interpretation. The lack of relevant articles on the subject of the present article was problematic in the initial phases of the research: there is little published research on the child as the health-promoting actor in the family, and no material about the Arctic or other Indigenous areas that focused on use of family network for promoting health. However, Weber's framework succeeded in tying together the areas of representation and interpretation by using the same framework for collation and categorizing of the data, and in the analysis. This was a strength, especially in the process of analysis, because it was possible to use one theory throughout the research process. There is always a schism between researchers' differing concepts of validity, reliability, variables and methods of coding. A larger empiri would have supported the accuracy, validity and reliability of the method.

\section{Conclusion}

The Convention on the Right's of the Child states that every child has the right to life, to survival and development ${ }^{1}$. These rights are not only fundamental rights of life and but also encompass physical, psychological, social and spiritual health. It is not enough to know and understand that by focusing on the child as the health-promoting agent in the family, the focus of public health initiatives takes on a new direction and viewpoint. More research is needed to support the concept of children as promoters of their own health. By regarding the child as both an independent and a cointerdependent entity the focus is moved from viewing children as the receiver of health towards them being the promoters, stakeholders and key figures in shaping their own health. The child is then seen not only as the healthpromoting agent of their own health, but also the promoter of the health of their families.

\section{Acknowledgement}

The first author thanks her doctoral supervisor and co-author, Ina Borup for her support. Also acknowledged is the Nordic School of Public Health and the Greenlandic Research Council, for their financial support. 


\section{References}

1. United Nations. Convention on the Rights of the Child. Geneva: UN, 1990. Available: http://www2.ohchr.org/english/law/crc.htm (Accessed 5 March 2012).

2. Schweitzer P, Irlbacher Fox S, Csonka Y, Kaplan L. Cultural Well-being and Cultural Vitality. In: J Nymand Larsen, P Schweitzer, G Fondahl (Eds). Arctic social indicators: a follow-up to the AHDR. Copenhagen: ASI Secretariat, Stefansson Arctic Institute, 2010.

3. Ladd-Yelk C. Resiliency factors of the North-American Indigenous people. Stout, WI: The Graduate College of University of Wisconsin, 2001.

4. Smith L. Dis-colonizing methodology. London: Zed, 2003.

5. Montgomery-Andersen R, Willen H, Borup I. 'There was no other way things could have been.' Greenlandic women's experiences of referral and transfer during pregnancy. Anthropology \&Medicine 2010; 17(3): 301-313.

6. Schor E, Menaghan EG. Family Pathways to Child Health. In: A Benjamin, S Levine, AD Walsh (Ed). Society and Health. New York, Oxford University Press, 1995.

7. Weber R. Basic content analysis, quantitative applications in the social sciences. Newbury Park, CA: Sage, 1990.

8. Cross T. Understanding family resiliency from a relational world-view. In: HI McCubbin, EA Thompson, AI Thompson, JE Fromer (Eds). Resiliency in Native American and immigrant families. Thousand Oaks, CA: Sage, 1998; 143-157.

9. Trondheim G. Kinship in Greenland - Emotions of Relatedness. Acta Borealia 2010; 27(2): 208-220.

10. Nuttall M. Arctic Homeland: Kinship, Community and Development in Northwest Greenland. Toronto: University of Toronto Press, 1992.
11. Daviss B. The Canary, the Whale and the Inuit. In: R Davis-Floyd, C Sargent. Childbirth and Authoritative Knowledge. Cross-cultural perspectives. Berkeley, CA: University of California Press, 1997.

12. O'Niel JD, Kaufert JM. Politics of obstetric care: the Inuit experience. In: W Handwerker (Ed.). Births and power: Social change and the politics of reproduction. London: Westview, 1997; 325-345.

13. Christensen P. The health-promoting family: a conceptual framework for future research. Social Science \& Medicine 2004; 59: 377-387.

14. Condon RG. Adolescence and changing family relations in the Central Canadian Arctic. Arctic Medical Research 1990; 49: 81-92.

15. Berkman LF. The role of social relations in health promotion. Psychosomatic Medicine 1995; 57: 245-254.

16. Mohajer N, Bessarab D, Earnest J. There should be more help out here! A qualitative study of the needs of Aboriginal adolescents in rural Australia. Rural and Remote Health 9: 1137. (Online) 2009. Available: www.rrh.org.au (Accessed 24 October 2011).

17. Richmond CAM, Ross N. Social support, material circumstance and health behaviour: Influences on health in First Nation and Inuit communities of Canada. Social Science \& Medicine 2008; 67: 1423 1433.

18. Durkeheim E, Mauss M. Primitive Classification. Cited in: R Needham, EE Evans-Pritchard. English introduction to Primitive Classifications by Social Anthropology. London: Routlege and Kegan Paul, 1951; 80 .

19. Montgomery-Andersen R. Referral in Pregnancy. A challenge for Greenlandic Women. Gøteborg, Sweden. Nordic School of Public Health, 2005.

20. Cassidy C. Child and community of philosophical inquiry. Childhood \& Philosophy 2006: 2(4): 1-19. 
The International Electronic Journal of Rural and Remote Health Research, Education Practice and Policy

21. McCall C. Stevenson lectures on citizenship. Cited in: Cassidy

C. Child and community of philosophical inquiry. Childhood \& Philosophy 2006: 2(4): 1-19.

22. Christensen P. Children's participation in ethnographic research: Issues of power and representation. Children \& Society 2004; 18: 165-176.

23. Letcher A, Perlow K. Community-based participatory research shows how a community initiave creates networks to improve wellbeing. American Journal of Preventative Medicine 2009; 37: S292-S299.
24. Niclasen B. Folkesundhed i børnehøjde - indikatorer for børns sundhed og velbefindende i Grønland [Public Health at the child's level - Indicators for children's health and wellbeing in Greenland]. Gøteborg, Sweden: Nordic School of Public Health, 2009. (In Swedish)

25. Kostenius C. Giving Voice and Space to Children in Health Promotion. Dissertation. Luleå: Luleå University of Technology Department of Health Science, 2008. 